\title{
Biochemical and Molecular Genetic Predictors of Genital Prolapse
}

\author{
Daria M Lukyanova* \\ Department of Obstetrics and Gynecology, Pirogov Russian National Research Medical University, Russia
}

Submission: December 12, 2017; Published: January 12, 2018

*Corresponding author: Daria M Lukyanova, Department of Obstetrics and Gynecology, Pirogov Russian National Research Medical University, Moscow, Russia, Tel: +79262942949; Email: dasha-lukyanova9@mail.ru

\begin{abstract}
Objective: To study the presence of gene polymorphisms of extracellular matrix structural components and metabolism enzymes, receptors activity and mechanisms of intracellular regulation of the connective tissue in women with genital prolapse.

Subjects and methods: Analysis of published data on genetic polymorphisms and biochemical mechanisms of genital prolapse is presented.

Results: The paper presents the morden data on the impact of genetic polymorphisms on genital prolapse predisposition. It describes appropriate molecular genetic and biochemical processes of pathological connective tissue formation of pelvic organs and the pelvic complex in women with genital prolapse.

Conclusion: Genital prolapse is a multifactorial pathology with various pathological both extra- and intracellular mechanisms. At the moment, a lot of genetic variants are not specific only for this disease. There is no uniform consensus on the pathogenesis of the disease. Therefore, it is necessary to identify the specific molecular genetic markers of susceptibility to genital prolapse and identify high-risk groups, as well as the result prediction of surgical treatment.
\end{abstract}

Keywords: Genital prolapsed; COL3A1; FBLN5; LOX polymorphisms; Connective tissue dysplasia; TGF- $\beta 1$.

\section{Introduction}

Genital prolapse (GP) is a serious problem with high prevalence among the female population. It is due to adjacent organ dysfunction and a high rate of relapse after surgical treatment. The prevalence of GP varies from 4.5 to $30 \%$. The risk factors of GP, such as increased abdominal pressure, difficult delivery, altered hormone imbalance, lead to abnormal remodeling of extracellular matrix. This disorder changes the normal architectonics and mechanical properties of pelvic floor tissues [1].

There is a hereditary predisposition to $\mathrm{PG}$ in $33 \%$ of cases. Genital prolapse is often accompanied by other clinical manifestations of connective tissue dysplasia [2]. The identification of genetic polymorphisms determining predisposition to GP are important.

\section{Discussion}

At the moment more than 30 genetic polymorphisms which can cause functional disorders of pelvic organs are described [3].
The expression of genes encoding the type I collagen alpha- 1 and the type III collagen alpha-1 plays a key role in GP pathogenesis. The polymorphism of $\alpha 1$ chain gene (COL1A1) is induced by the substitution of a guanidine residue to thymidine residue at the Sp1-binding site of the COLIA1 gene [4]. This mutation leads to increased synthesis of RNA of the mutant allele and disruption of the normal structure of type I collagen. Type III collagen is an important factor in the repair of connective tissue. A single-nucleotide substitution in the coding region of type III collagen (COL3A1) showed to be a relevant risk factor for POP [5]. In this case alanine is replaced by threonine in all chains of the type III collagen. The structure of the whole helix changes and causes mechanical characteristic reduction and strength disruption of the pelvic floor.

Alarab et al. found that the expression of lysyloxidase (LOX) and lysyloxidase-like enzymes L1 and L3 (LOXL1, LOXL3) in vaginal tissue of women with pelvic organ prolapsed was significantly reduced [6]. These enzymes catalyze the processes 
of collagen and elastin post-translational modifications. LOXL1 localizes specifically to sites of elastogenesis and interacts with fibulin-5. This process stabilizes the outer surface of cell walls and organizes elastin polymers into functional elastic fibers [7]. It has been shown that reduced expression of LOX, LOXL1 and LOXL3 genes can lead to connective tissue disruption and pelvic organ prolapse development [8].

In addition, single-nucleotide polymorphisms rs2018736 and rs12589592 of the fibulin-5 gene (FBLN5) determine predisposition to genital prolapse [9]. Fibulin-5 is secreted by endothelial cells, vessel smooth muscle cells, and fibroblasts. Fibulin-5 contains an evolutionally conserved arginine-glycineaspartic acid (RGD) motif in the N-terminal region, which mediates binding to a subset of integrins, including $\alpha 5 \beta 1, \alpha v \beta 3$, and $\alpha v \beta 5$. They are involved in intercellular interactions [10]. The reduction in FBLN5 expression in vagina walls and pelvic organ ligaments decreases the expression of LOX enzymes and increases protease activity $[11,12]$. This leads to GP development and also increases the risk of GP recurrence after surgical treatment.

Missense mutations of a new locus WNK1 (with no lysine kinase) are involved in the pathogenesis of PG [13]. WNK1 protein a regulator of a variety of intracellular signaling pathways including the Wnt/ $\beta$-catenin pathway. The latter affects the formation of the mitotic spindle [14]. The mutation of the WNK1 locus causes a slow growth and proliferative activity of the fibroblasts in uterine ligaments and a decrease of collagen synthesis.

At the moment, the role of transforming growth factor beta1 (TGF- $\beta 1$ ) in the pathogenesis of GP has been proven [15]. TGF- $\beta 1$ stimulate collagen synthesis enhancing extracellular matrix formation. The decreased expression of TGF- $\beta 1$ causes a decreased expression of connective tissue growth factor (CTGF) which leads to a slower growth and differentiation of fibroblasts and reduced synthesis of extracellular matrix components $[16,17]$. In parallel, the activation of matrix metalloproteinases (MMPs) and inhibition of tissue inhibitors of metalloproteinases (TIMPs) occurs. They cause increased fragmentation of fibers, aggravates the structural reorganization of connective tissue, reduces its strength and elasticity. This is manifested by the development of GP and stress urinary incontinence [18].

Another mechanism is the induction of expression of lysyloxydase-like enzyme-4 (LOXL4). The TGF-beta1 regulation of LOXL4 expression is mediated through the binding of AP1 transcription factor to a conserved region of the promoter. This enzyme potentiates the processes of post-translational modifications of collagen and elastin, LOXL4 also suppresses the activity of MMP2. LOXL4 may function as a negative feedback regulator of TGF-beta1 in cell invasion by inhibiting the metabolism of extracellular matrix components that leads to an increased risk of GP [19].

\section{Conclusion}

Thus some of the mechanisms of genital prolapse development have been identified. However, there are many counterarguments regarding the pathogenesis of GP. The detected genetic variants are non-specific only for this disease. It is necessary to determinate predictors of GP and effective treatment modes.

\section{References}

1. Chen B Yeh J (2011) Alterations in connective tissue metabolism in stress incontinence and prolapse. J Urol 186(5): 1768-1772.

2. Norton PA, Allen-Brady K, Cannon-Albright LA (2013) The familiality of pelvic organ prolapse in the Utah Population Database. Int Urogynecol J 24(3): 413-418.

3. Cartwright R, Kirby AC, Tikkinen KA, Mangera A, Thiagamoorthy G, et al. (2015) Systematic review and metaanalysis of genetic association studies of urinary symptoms and prolapse in women. Am J Obstet Gynecol 212(2): 199.e1-24.

4. Cho HJ, Jung HJ, Kim SK, Choi JR, Cho NH, et al. (2009) Polymorphism of a COLIA1 gene Sp1 binding site in Korean women with pelvic organ prolapse. Yonsei Med J 50(4): 564-568.

5. Kluivers KB, Dijkstra JR, Hendriks JCM, Lince SL, Vierhout ME, et al. (2009) COL3A1 2209G $>A$ is a predictor of pelvic organ prolapse. Int Urogynecol J Pelvic Floor Dysfunct 20(9): 1113-1138.

6. Alarab M, Bortolini MA, Drutz H, Lye S, Shynlova O (2010) LOX family enzymes expression in vaginal tissue of premenopausal women with severe pelvic organ prolapse. Int Urogynecol J 21(11): 1397-1404.

7. Liu X, Zhao Y, Gao J, Pawlyk B, Starcher B, et al. (2004) Elastic fiber homeostasis requires lysyl oxidase-like 1 protein. Nat Genet 36 (2): 178-182.

8. Neupane R, Sadeghi Z, Fu R, Hagstrom SA, Moore CK, et al. (2014) Mutation screen of LOXL1 in patients with female pelvic organ prolapse. Female Pelvic Med Reconstr Surg 20(6): 316-321.

9. Khadzhieva MB, Kamoeva SV, Chumachenko AG, Ivanova AV, Volodin IV, et al. (2014) Fibulin-5 (FBLN5) gene polymorphism is associated with pelvic organ prolapse. Maturias 78(4): 287-292.

10. Yanagisawa H, Schluterman MK, Brekken RA (2009) Fibulin-5, an integrin-binding matricellular protein: its function in development and disease. J Cell Commun Signal 3(3-4): 337-347.

11. Zhou Y, Ling O, Bo L (2013) Expression and significance of lysyl oxidase-like 1 and fibulin-5 in the cardinal ligament tissue of patients with pelvic floor dysfunction. J Biomed Res 27(1): 23-28.

12. Hu Q Loeys BL, Coucke PJ, De Paepe A, Mecham RP, et al. (2006) Fibulin-5 mutations: mechanisms of impaired elastic fiber formation in recessive cutis laxa. Hum Mol Genetn 15(23): 3379-1386.

13. Rao S, Lang J, Zhu L, Chen J (2015) Exome sequencing identifies a novel gene, WNK1, for susceptibility to pelvic organ prolapse (POP). PLoS One 10(3).

14. Wang Z, Shi HH, Chen G (2012) Role of canonical Wnt signaling transduction pathway in the pathogenesis of pelvic organ prolapse. J Chin Med Assoc 92(24): 1669-1673.

15. Meijerink AM, van Rijssel RH, van der Linden PJv (2013) Tissue composition of the vaginal wall in women with pelvic organ prolapse. Gynecol Obstet Invest 75(1): 21-27.

16. Li BS, Hong L, Min J, Wu DB, Hu M, et al. (2013) The expression of glutathione peroxidase- 1 and the anabolism of collagen regulation pathway transforming growth factor-beta1-connective tissue growth 
factor in women with uterine prolapse and the clinic significance. Clin Exp Obstet Gynecol 40(4): 586-590.

17. Qi XY, Hong L, Guo FQ, Fu Q Chen L, et al. (2011) Expression of transforming growth factor-beta 1 and connective tissue growth factor in women with pelvic organ prolapse. Saudi Med J 32(5): 474-478.

18. Sun B, Zhou L, Wen Y, Wang C, Baer TM, et al. (2014) Proliferative behavior of vaginal fibroblasts from women with pelvic organ prolapse. Eur J Obstet Gynecol Reprod Biol 183: 1-4.
19. Kim DJ, Lee DC, Yang SJ, Lee JJ, Bae EM. et al. (2008) Lysyl oxidase like 4, a novel target gene of TGF-beta1 signaling, can negatively regulate TGFbeta1-induced cell motility in PLC/PRF/5 hepatoma cells. Biochem Biophys Res Commun 373(4): 521-527.
This work is licensed under Creative Commons Attribution 4.0 Licens

DOI: $10.19080 / J G W H .2018 .08 .555730$
Your next submission with Juniper Publishers will reach you the below assets

- Quality Editorial service

- Swift Peer Review

- Reprints availability

- E-prints Service

- Manuscript Podcast for convenient understanding

- Global attainment for your research

- Manuscript accessibility in different formats

( Pdf, E-pub, Full Text, Audio)

- Unceasing customer service

Track the below URL for one-step submission https://juniperpublishers.com/online-submission.php 